\title{
LA PLANEACIÓN PARTICIPATIVA COMUNITARIA COMO HERRAMIENTA METODOLÓGICA PARA LA CONFORMACIÓN DE SUJETOS COLECTIVOS RURALES
}

\section{COMMUNITY PARTICIPATORY PLANNING AS A METHODOLOGICAL TOOL FOR THE CONFORMATION OF RURAL COLLECTIVE SUBJECTS}

\author{
J. José Rojas-Herrera ${ }^{*}$, Rogel del Rosal-Valladares ${ }^{2}$ \\ ${ }^{1}$ Universidad Autónoma Chapingo (rojashjj@gmail.com). ${ }^{2}$ Asociación Civil Yankuik Erandi \\ Rural (hualkad@yahoo.com.mx)
}

\begin{abstract}
RESUMEN
En este artículo se comparten los resultados derivados de la ejecución de un proyecto de investigación-acción bajo el método del diagnóstico y la planeación comunitaria participativa, realizado en 17 comunidades rurales de cuatro estados de la República mexicana. El objetivo general del proyecto consistió en realizar diagnósticos participativos que condujeran a la elaboración de planes de desarrollo comunitario de carácter integral, concebidos como herramientas de planeación y conducción del desarrollo local. Entre los resultados alcanzados destacan el alto grado de apropiación de la metodología por parte de los participantes, la identificación de problemas comunes y el descubrimiento de potencialidades subyacentes, tales como: la existencia de abundantes recursos naturales y de infraestructura productiva instalada, la prevalencia de prácticas de trabajo colectivo voluntario y no remunerado, y diversos componentes de capital social en estado latente. Con base en lo anterior, es posible concluir que la metodología utilizada contribuye a la configuración de sujetos colectivos rurales con proyecto propio y que, por ende, las comunidades que han participado están ahora mejor capacitadas, desde el punto de vista organizacional, para retener a la población en sus lugares de origen y para evitar caer en la tragedia de los comunes.
\end{abstract}

Palabras clave: capital social, investigación-acción, organización de productores, sujetos rurales.

\section{INTRODUCCIÓN}

$\mathrm{E}$ n este artículo se comparten los resultados y conclusiones derivadas de la ejecución de un proyecto de investigación-acción bajo el método del diagnóstico y la planeación comunitaria partici-

* Autor responsable * Author for correspondence. Recibido: febrero, 2018. Aprobado: julio, 2019.

Publicado como ARTÍCULO en ASyD 18: 105-126. 2021.
ABSTRACT

This article presents the results derived from the execution of a research-action project under the method of diagnosis and community participatory planning, performed in 17 rural communities of four states in the Mexican Republic. The general objective of the project consisted in performing participatory diagnoses that could lead to the elaboration of integral community development plans, conceived as tools for planning and conducting local development. Among the results reached, the following stand out: high degree of appropriation of the methodology by the participants, identification of common problems and discovery of underlying potentialities, such as: the existence of abundant natural resources and installed productive infrastructure, the prevalence of practices of voluntary and unpaid collective work, and various components of social capital in latent state. Based on this, it is possible to conclude that the methodology used contributes to the configuration of collective rural subjects with a project of their own and that, therefore, the communities that have participated are now better trained, from the organizational point of view, to retain the population in their places of origin and to avoid falling into the tragedy of the commons.

Keywords: research-action, producers' organization, rural subjects, social capital.

\section{INTRODUCTION}

This article presents the results and conclusions derived from the execution of a research-action project under the method of diagnosis and community participatory planning, performed in 17 rural communities of four states of the Republic. This project started in April 2014 and concluded formally in March 2016, although throughout 2016 and the 
pativa, realizado en 17 comunidades rurales de cuatro estados de la República. Dicho proyecto arrancó en abril de 2014 y concluyó formalmente en marzo de 2016, si bien a lo largo de 2016 y el primer semestre de 2017 se realizaron diversas actividades de seguimiento y evaluación de resultados. Su objetivo general consistió en realizar diagnósticos participativos que condujeran a la elaboración de planes de desarrollo comunitario de carácter integral, concebidos como herramientas de planeación y conducción del desarrollo local de las comunidades participantes y como posible respuesta organizada al fenómeno de la migración forzada que, por razones económicas, arrastra a un número creciente de trabajadores del campo.

La hipótesis central de trabajo postuló que las comunidades rurales del país eran capaces de involucrarse en procesos de diagnóstico y planeación participativa, que les permitirían habilitarse para evitar caer en la llamada tragedia de los comunes ${ }^{3}$ y les ofrecerían la oportunidad de convertirse en actores de su propio desarrollo autónomo.

El financiamiento para la puesta en marcha del proyecto de mérito, se integró como resultado de una mezcla de recursos procedentes de las fundaciones norteamericanas: Vista Hermosa (FVH) e Interamericana (IAF), así como aportaciones en especie y trabajo, de parte de las organizaciones integrantes de la Red Campesina de Pequeños Productores de México (RCPP). La planeación, coordinación, implementación y sistematización general corrió a cargo de la Asociación Civil Yankuik Erandi Rural, A.C. (ERANDI), constituida en marzo de 2013, como organismo de apoyo técnico al servicio de la RCPP. De igual modo y con el propósito de garantizar la adecuada conducción metodológica del proceso en su conjunto, ERANDI contó con el apoyo técnico de asesores externos, expertos en la metodología de los diagnósticos participativos, que fueron contratados ex profeso.

La RCPP, creada en 2009, es un organismo de integración nacional de ocho organizaciones campesinas regionales que, a lo largo de su trayectoria histórica, han acumulado muy diversas experiencias y han reconocido la importancia de articularse entre sí para potenciar el efecto de su acción colectiva. Tales organizaciones son: el Frente Democrático Campesino de Chihuahua (FDCCH), la Coordinadora de Organizaciones Campesinas e Indígenas de la Huasteca Potosina (COCIHP), el colectivo Comunidad Fértil de Tabasco, y las organizaciones oaxaqueñas: first semester of 2017 various activities were carried out to follow and evaluate the results. The general objective consisted in performing participatory diagnoses that could lead to the elaboration of integral community development plans, conceived as tools for planning and conducting local development of the participating communities and as possible organized response to the phenomenon of forced migration which drags a growing number of workers from the field, due to economic reasons.

The central working hypothesis proposes that rural communities of the country are capable of becoming involved in processes of diagnosis and participatory planning, which would allow them to be prepared to avoid falling into the so-called tragedy of the commons ${ }^{1}$ and would offer the opportunity of becoming actors of their own autonomous development.

Financing for the implementation of the merit project was integrated as a result from a mix of resources from North American foundations: Vista Hermosa (VHF) and Interamericana (IAF), as well as contributions in kind and work, from the organizations that are members of the Network of Peasant Small-Scale Producers (Red Campesina de Pequeños Productores de México, RCPP). Planning, coordination, implementation and general systemization was the responsibility of the Civil Association Yankuik Erandi Rural, A.C. (ERANDI), constituted in March 2013 as agency of technical support for the RCPP service. Likewise, and with the purpose of ensuring the adequate methodological conduction of the process as a whole, ERANDI had the external technical support of experts in the methodology of participatory diagnosis, who were hired deliberately.

The RCPP, created in 2009, is an agency of national integration of eight regional peasant organizations, which have accumulated quite diverse experiences throughout their historical trajectory and have recognized the importance of becoming articulated with one another in order to potentiate the effect of their collective action. Such organizations are: the Frente Democrático Campesino de Chihuahua (FDCCH), the Coordinadora de Organizaciones Campesinas e Indigenas de la Huasteca Potosina (COCIHP), the collective Comunidad Fértil de Tabasco, and the organizations in Oaxaca: Yeni Navan (MICHIZA), Centro para el Desarrollo 
Yeni Navan (MICHIZA), Centro para el Desarrollo Comunitario (Centeotl), Centro para el Desarrollo Integral Campesino de la Mixteca (CEDICAM), Coordinación Pasado, Presente y Futuro de Miramar (COPPFUMIR) y Puente a la Salud Comunitaria.

El presente documento está estructurado en tres apartados. En el primero de ellos, se exponen los fundamentos teórico-metodológicos en los que se basó la ejecución del proyecto, describiendo las actividades realizadas y presentando algunos de los problemas de orden técnico y operativo que se presentaron durante la fase de implementación, así como la forma en que éstos fueron atendidos. En el segundo, se muestran los resultados alcanzados y, en el tercer y último apartado, se presentan las conclusiones generales del estudio.

\section{MARCO CONCEPTUAL Y METODOLÓGICO}

De acuerdo con diversos autores, entre quienes destacan Alain Touraine (1987) y Gregorio Vidal (2012), un actor social es un sujeto colectivo estructurado e integrado en torno a una identidad o razón de vida común, que dispone de un determinado número de recursos que le permiten actuar en el seno de una sociedad con vistas a defender los intereses de los miembros que lo componen o de los individuos que representa, a fin de dar respuesta a las necesidades identificadas por éstos como prioritarias. En este sentido, los actores sociales no surgen espontáneamente, sino que se configuran a sí mismos, de acuerdo con la identidad compartida y el carácter intencionado que imprimen a sus acciones a lo largo del tiempo. De forma análoga, un actor social puede ser concebido como un grupo de intervención, que percibe a sus miembros como fuerza transformadora de su realidad inmediata y como constructores de su historia, lo que significa que el actor social actúa sobre el exterior, pero también sobre sí mismo. En ambos casos, el actor se ubica como sujeto colectivo, entre el individuo y el Estado y es generador de estrategias de acción, que contribuyen a la gestión y transformación de la sociedad.

Con base en lo anterior, podemos estimar que, en el medio rural del país, los sujetos o actores sociales, ya sean grupos o instituciones de carácter público o privado, son las partes beligerantes cuyos intereses y proyectos pueden resultar afectados por un problema o acción colectiva. También pueden ser aquellos
Comunitario (Centeotl), Centro para el Desarrollo Integral Campesino de la Mixteca (CEDICAM), Coordinación Pasado, Presente y Futuro de Miramar (COPPFUMIR) and Puente a la Salud Comunitaria.

This document is structured in three sections. The first one exposes the theoretical-methodological foundations on which the execution of the project was based, describing the activities carried out and presenting some of the technical and operative problems that were present during the phase of implementation, as well as the way in which these were addressed. The second section shows the results attained, and the third and last section presents the general conclusions of the study.

\section{CONCEPTUAL AND METHODOLOGICAL FRAMEWORK}

According to various authors, among whom Alain Touraine (1987) and Gregorio Vidal (2012) stand out, a social actor is a structured collective subject integrated around a common identity or life reason, who makes use of a specific number of resources that allows acting in the midst of a society with the intent to defend the interests of members that compose it and/or the individuals that it represents, in order to respond to the needs identified by these as priority. In this sense, social actors do not emerge spontaneously, but rather they become configured according to the identity shared and the intended character that they impress on their actions throughout time. In an analogous way, a social actor can be conceived as an intervention group, which perceives its members as a transforming force of their immediate reality and as constructors of their own story, which means that the social actor acts on the exterior, but also on itself. In both cases, the actor is found as a collective subject, between the individual and the State, and is generator of action strategies that contribute to society's management and transformation.

Based on this, we can estimate that in rural areas of the country, the subjects or social actors, whether groups or public or private institutions, are the conflicting parts whose interests and projects can be affected by a problem or collective action. They can also be those interest groups with possibilities of influencing the problem or the action, through use of the means available, such as power, legitimacy, and prevalent collaboration and conflict links. Therefore, 
grupos de interés con posibilidades de incidir en el problema o la acción, a través del uso de los medios que estén a su disposición, tales como el poder, la legitimidad y los vínculos de colaboración y conflicto prevalecientes. Por consiguiente, la intervención de los actores sociales debe ser examinada a partir de su representatividad al interior de la sociedad y de su capacidad para transformar los conflictos sociales en nuevas reglas institucionales.

Lamentablemente, como han señalado diversos autores, entre quienes podemos mencionar a Gabriel Quadri (2006) y Carla Zamora (2011), en el diseño e implementación de programas de desarrollo rural, es recurrente considerar a la población del campo sólo como objeto de las acciones y la política pública y no como sujetos activos del cambio. Bajo esta lógica, las políticas públicas se conciben y aplican "de arriba-abajo", como procesos de una sola vía o una única fuente de la que emana toda la información, los conocimientos, las destrezas y, por supuesto, la tecnología y el financiamiento necesarios para que se alcance el desarrollo rural.

Este tipo de programas están condenados desde el principio al fracaso debido a que no logran vencer las resistencias de las comunidades a participar en la implementación de acciones y proyectos, definidos sin su participación. En estas condiciones, buena parte de los recursos destinados a los proyectos de desarrollo rural son capturados por los grupos más influyentes y con mayor poder económico, con mayores relaciones, más información y mejores niveles educativos, excluyendo a los sectores más pobres y peor posicionados en el escenario local, fenómeno que, paradójicamente, reproduce y amplía las brechas de desigualdad social y económica pre existentes.

No obstante, una de las formas posibles y más prometedoras para enfrentar dichos males, consiste en implementar metodologías de trabajo que involucren a la población en la identificación de sus recursos naturales y en el desarrollo de sus potencialidades productivas, mediante técnicas apropiadas que tomen en cuenta las condiciones, necesidades, y oportunidades locales, desencadenando la más amplia participación de los distintos sectores y grupos que integran una comunidad, sin discriminación ni exclusión alguna. Se trataría así de echar mano de una herramienta metodológica que, además, se distinga por ser sencilla, accesible, de fácil manejo, altamente participativa, y, sobre todo, útil para la comunidad en su conjunto. the intervention of social actors ought to be examined based on their representativeness inside society and their ability to transform social conflicts into new institutional rules.

Regretfully, as various authors have pointed out, among which we can mention Gabriel Quadri (2006) and Carla Zamora (2011), in the design and implementation of rural development programs, it is recurring to consider the rural population as simply the object of actions and public policy and not as active subjects of change. Under this logic, public policies are conceived and applied "top-down" as one-way processes or with a single source from which all information, knowledge, skills, and naturally technology, emanate, as well as the financing necessary for rural development to be reached.

This type of programs are doomed to failure from the beginning because they do not manage to defeat the resistances of communities when participating in the implementation of actions and projects, defined without their participation. Under these conditions, a good part of the resources destined to rural development projects are captured by the groups with most influence and highest economic power, with more relationships, more information and higher educational levels, excluding the poorest sectors which have the worst position in the local scenario, a phenomenon that paradoxically reproduces and broadens the gaps of pre-existing social and economic inequality.

Nevertheless, one of the possible and more promising ways of facing these evils consists in implementing working methodologies that involve the population in the identification of their natural resources and in the development of their productive potentialities, through appropriate techniques that take into consideration the local conditions, needs and opportunities, triggering the broadest participation from different sectors and groups that integrate a community, without any discrimination or exclusion. This way there would be an attempt to use a methodological tool that, in addition, is differentiated by being simple, accessible, of easy management, highly participative, and above all useful to the community as a whole.

Since some decades ago, a methodology that has been outlined with the possibility of gathering those characteristics, is participatory diagnosis ${ }^{2}$, insofar as it is truly appropriate for the community and 
Desde hace unas cuantas décadas, una metodología que se ha perfilado con posibilidades de reunir tales características, es la de los diagnósticos participativos ${ }^{4}$, siempre que ésta sea verdaderamente apropiada por la comunidad y se utilice con creatividad y flexibilidad. Una experiencia de aplicación reciente de la misma se expone en este trabajo, aunque es importante insistir en que su adaptación y experimentación en nuestro país tiene ya una larga tradición, si bien ha cobrado fuerza en el presente siglo, a partir del interés de organismos internacionales del Sistema de Naciones Unidas como el Alto Comisionado de las Naciones Unidas para los Refugiados (ACNUR, 2006) y la Organización para la Alimentación y la Agricultura (FAO, 2008), las cuales la han utilizado y difundido ampliamente en sus misiones y programas institucionales. En la esfera del gobierno federal, destaca la labor de extensión realizada por la Comisión Nacional Forestal (CONAFOR, 2014), a través de su Gerencia de Silvicultura Comunitaria que ha impulsado en diversas regiones del país el Programa de Desarrollo Forestal Comunitario y, desde el ámbito teórico y académico, merecen ser reconocidos los trabajos de: Tillmann y Salas,1994; Chambers, 1997; Hewerg y Steiner, 2002; Geilfus, 2002; Verdejo, 2003; Chevalier y Buckles, 2009; y Terrones y Sánchez, 2010.

Un breve resumen de sus fundamentos epistemológicos, podría formularse de la siguiente manera:

1) Un diagnóstico comunitario es un momento de un proceso de concientización, organización y movilización social, orientado al desarrollo local, que permite sensibilizar a los habitantes de una comunidad respecto a la realidad que enfrentan, a fin de identificar las dificultades que el grupo presenta en su interior, registrar los activos y recursos tangibles e intangibles disponibles, conocer las oportunidades y amenazas del entorno y dotar a la comunidad de un proyecto compartido de futuro. Dicho en términos más precisos, el diagnóstico comunitario es un instrumento metodológico que ayuda a las comunidades a interpretar su propia realidad y a definir mecanismos para su transformación planificada, lo cual les otorga capacidad real para controlar su propia situación de vida.

2) Todo diagnóstico comunitario requiere ser actualizado constantemente, ya que la realidad está siempre en movimiento. Técnicamente hablando supone la used with creativity and flexibility. An experience of recent application of this tool is exposed in this study, although it is important to insist that its adaptation and experimentation in our country already have a long tradition, although it has gained strength in this century, based on the interest of international organizations from the United Nations System such as the UN Refugee Agency (ACNUR, 2006) and the Food and Agriculture Organization of the United Nations (FAO, 2008), which have been used and broadly disseminated in their institutional missions and programs. In the sphere of the federal governments, the extension work performed by the National Forest Commission (Comisión Nacional Forestal, CONAFOR, 2014) stands out, through its Community Forestry Development Program, and from the theoretical and academic sphere, the following studies should be recognized: Tillmann and Salas, 1994; Chambers, 1997; Hewerg and Steiner, 2002; Geilfus, 2002; Verdejo, 2003; Chevalier and Buckles, 2009; and Terrones and Sánchez, 2010.

A brief summary of its epistemological foundations could be formulated in the following way:

1) A community diagnosis is a moment of a process of gaining awareness, organization and social mobilization, directed at local development, which allows sensitizing the inhabitants of a community with regard to the reality that they face, in order to identify the difficulties that the group presents in it, record the assets and tangible and intangible resources available, understand the opportunities and threats of the environment, and give the community a shared future project. In more accurate terms, community diagnosis is a methodological instrument that helps the communities to interpret their own reality and to define mechanisms for their planned transformation, which grants them real capacity to control their own life situation.

2) Every community diagnosis requires being constantly updated, since reality is always in motion. Technically speaking it entails the systematic recollection and analysis of information with the aim of defining whether they are generating processes of change. Therefore, the community diagnosis, rather than being an evaluation that is carried out only once, 
recolección y análisis sistemáticos de información con la finalidad de determinar si se están generando procesos de cambio. Por tanto, el diagnóstico comunitario, más que una evaluación que se realiza una sola vez, es un proceso continuo en el que los habitantes de una comunidad registran sistemáticamente información relativa a sus problemas y proyectos colectivos y, dentro de una perspectiva de largo plazo, tiende a convertirse en parte de la cultura organizacional de las comunidades.

3) El diagnóstico comunitario se hace siempre a partir de los conocimientos y saberes locales, contrastados con los datos e indicadores oficiales. Se trata de un proceso de aprendizaje colectivo en cuyo marco se posibilita que unos aprendan de otros y se alcance una mejor comprensión de la dinámica propia de la comunidad en cuestión.

4) La práctica del diagnóstico comunitario favorece la cultura democrática en la toma de decisiones respecto al uso y conservación de los recursos naturales y demás asuntos que les afectan, así como en la definición de las propuestas de solución a los problemas comunes.

5) El diagnóstico comunitario participativo es realizado por la propia comunidad, ya sea que se trate de un grupo pequeño o grande o un conjunto de grupos. Lo importante es que sea efectuado por las personas que directamente son afectados en su vida cotidiana por un problema determinado. Los agentes externos actúan solamente como facilitadores, pero en ninguna circunstancia o condición sustituyen a los pobladores locales.

6) Los acuerdos alcanzados se recuperan en un documento ejecutivo que servirá de base para el diseño de estrategias de acción colectiva y para la elaboración de normas y reglamentos, en los que se plasmen los derechos y deberes aceptados por los habitantes de la comunidad, a fin de lograr una convivencia basada en la justicia, la paz y la dignidad de todas las personas. De este modo, la comunidad se va autoconstruyendo y renovando en el tiempo, a partir de los acuerdos comunitarios adoptados en forma democrática.

7) El diagnóstico comunitario hacia afuera o en relación con los grupos de interés externo, constituye una herramienta que permite a la comunidad demandar a los poderes públicos el cumplimiento de los derechos ciudadanos y comunitarios consagrados en leyes y reglamentos de orden municipal, is a continuous process where the inhabitants of a community systematically record information relative to their collective problems and projects and, within a long-term perspective, tends to become part of the organizational culture of the communities.

3) Community diagnosis is always made from local knowledge and understanding, contrasted with official data and indicators. This is a collective learning process which has a framework that makes possible for some to learn from others, and for a better understanding of the own dynamic of the community in question.

4) The practice of community diagnosis favors democratic culture in decision making regarding the use and conservation of natural resources and other issues that affect them, as well as in the definition of proposals for solution to common problems.

5) Participatory community diagnosis is carried out by the community itself, whether it's a small or large group or a set of groups. The important thing is for it to be performed by the people who are directly affected in their daily life by a specific problem. External agents act solely as facilitators, but under no circumstance or condition do they substitute the local inhabitants.

6) The agreements reached were recovered in an executive document that will serve as the basis for the design of collective action strategies and for the elaboration of norms and regulations, where the rights and obligations accepted by the members of the community are set out, in order to achieve a coexistence based on justice, peace and dignity of all the people. Therefore, the community is selfconstructed and renovated in time, based on the community agreements adopted democratically.

7) Community diagnosis toward the outside or in relation to external interest groups constitutes a tool that allows the community to demand from public powers the fulfillment of citizen and community rights established in laws and regulations of the municipal, state or federal order, establishing the mechanisms of coparticipation of the community in the observance and accounting of those rights and privileges. It is, at the same time, a catalyzer of collective action that allows mobilizing community energy toward various actions of policy management and having 
estatal o federal, estableciendo los mecanismos de co-participación de la comunidad en la observancia y contraloría de dichos derechos y prerrogativas. Es, asimismo, un catalizador de la acción colectiva que permite movilizar la energía comunitaria hacia diversas acciones de gestión e incidencia política que coadyuvan a mejorar el acceso y la utilización de los bienes y servicios públicos indispensables.

En síntesis, la metodología del diagnóstico comunitario, al ofrecer una comprensión más profunda e integral de la comunidad, contribuye a que la población participante adopte el proceso de planeación de su desarrollo de manera activa y consciente, de tal modo que esté en condiciones de asumir un papel proactivo en la gestión, ejecución y seguimiento de acciones estratégicas.

Para lograr lo anterior, si bien puede haber diversas maneras de hacer un diagnóstico comunitario, en el caso del estudio realizado, la metodología utilizada se desagregó en las siguientes fases:

a) De sistematización pre diagnóstica, con base en información procedente, por una parte, de fuentes documentales oficiales, tales como los Ayuntamientos, el INEGI y la Comisión Nacional para el Desarrollo de los Pueblos Indígenas (CDI) y, por la otra, de información aportada por las propias organizaciones integrantes de la RCPP. Toda la información recopilada, de una y otra fuente, se clasificó en 5 temas o ejes de trabajo: físicoambiental; histórico, cultural y de derechos; sociodemográfico; de desarrollo económico, y organizativo-institucional.

b) De diagnóstico participativo comunitario, el cual operó mediante talleres que incluyeron sesiones plenarias y trabajo en comisiones. En un primer momento, en la asamblea general comunitaria se precisaron los objetivos del diagnóstico y se formaron cinco comisiones de trabajo, encargadas de atender cada uno de los temas indicados en el inciso anterior. Estas comisiones trabajaron por separado y, al final, se reunieron en asamblea general para rendir su informe. Las actividades desplegadas durante esta fase permitieron la recuperación de elementos relevantes de la historia local; el registro de las formas de organización social que estructuran a la comunidad y, la identificación, political impact that contributes to improving the access and the utilization of essential public goods and services.

In sum, the methodology of community diagnosis, by offering a deeper and integral comprehension of the community, contributes to the participating population adopting the planning process of their development in an active and conscious way, so that it is in conditions of assuming a proactive role in the management, execution and monitoring of strategic actions.

To achieve this, although there can be various ways of making a community diagnosis, in the case of the study performed, the methodology used is disaggregated into the following phases:

a) Pre-diagnosis systematization based on information from official document sources such as the Town Councils, INEGI and the National Commission for the Development of Indigenous Peoples (Comisión Nacional para el Desarrollo de los Pueblos Indigenas, CDI), on the one hand, and on the other hand based on information contributed by the organizations that are members of the RCPP. All the information gathered, from one source and another, was classified in 5 themes or working axes: physical-environmental; historical, cultural and of rights; sociodemographic; of economic development; and organizationalinstitutional.

b) Community participatory diagnosis which operated through workshops that included plenary sessions and commission work. During the first moment, the objectives of the diagnosis were specified in the general community assembly and five working commissions were formed, in charge of addressing each of the themes indicated in the previous section. These commissions worked separately and, at the end, gathered in the general assembly to present their report. The activities displayed during this phase allowed recovering relevant elements from the local history; the record of social organization forms that structure the community and the identification, through a sketch, of basic services which they have, applying a quick evaluation to identify the most pressing problems and their possible solutions. Likewise, a plan of the average daily workday of men and

ROJAS-HERRERAy DEL ROSAL-VALLADARES

111 
mediante un croquis, de los servicios básicos con los que cuentan, aplicando una evaluación rápida para ubicar los problemas más acuciantes y sus posibles soluciones. De igual manera, se elaboró un esquema de la jornada diaria de trabajo promedio de los hombres y las mujeres, a fin de visibilizar los roles que se les asignan a unos y otras y evaluar el estado que guarda la equidad de género. $\mathrm{El}$ análisis de las labores productivas cotidianas se realizó alrededor del producto agrícola principal de la comunidad y en base al calendario productivo vigente. Por último, se elaboró un análisis FODA con la finalidad de identificar las fortalezas, oportunidades, debilidades y amenazas con que cuenta la comunidad.

c) De sistematización y ordenamiento de la información recopilada por las comisiones de trabajo. Esta labor la efectuó el equipo de apoyo técnico y se trató básicamente de un trabajo de gabinete, que dio origen a una especie de mapeo comunitario que permitió identificar y clasificar los principales problemas que afectan a las comunidades participantes.

d) Taller de validación de resultados, el cual tuvo como insumo principal el informe-diagnóstico que, con toda la información debidamente procesada y sistematizada, presentó el equipo de apoyo técnico a las autoridades locales y grupos de trabajo, quienes, a su vez, definieron propuestas de líneas estratégicas y proyectos concretos a implementar, facilitando la reflexión colectiva y la jerarquización de los problemas.

e) De aprobación del Plan de Desarrollo Comunitario en Asamblea General de la comunidad, lo que permitió identificar y validar las soluciones posibles a los problemas detectados, establecer los compromisos y responsabilidades a asumir de manera individual y colectiva, y definir el contenido de un plan para la acción inmediata, y

f) De seguimiento y evaluación de resultados de las acciones realizadas por cada una de las comunidades participantes. Dicho proceso de seguimiento y evaluación fue coordinado por diversos grupos de representantes comunitarios y supervisado regularmente, tanto por el equipo técnico como por las organizaciones integrantes de la RCPP.

Este ejercicio tuvo como principal producto: un documento-diagnóstico por comunidad, que muestra women was made, in order to make visible the roles that they are assigned, and to evaluate the state of gender equity. The analysis of the daily productive tasks was carried out around the main agricultural product of the community and based on the current productive calendar. Lastly, a SWOT analysis was elaborated with the aim of identifying the strengths, weaknesses, opportunities, and threats found in the community.

c) Systematization and ordering of the information gathered by the working commissions. This task was carried out by the technical support team and was basically desk work, which gave rise to a sort of community mapping that allowed identifying and classifying the main problems that affect the participating communities.

d) Workshop of results validation, which had as main input the diagnosis report which, with all the duly processed and systematized information, was presented by the technical support team to local authorities and work groups, who, in turn, defined proposals of strategic lines and concrete projects to be implemented, easing collective reflection and defining a hierarchy of problems.

e) Approval of the Community Development Plan in the community's General Assembly, which allowed identifying and validating the possible solutions to the problems detected, establishing the commitments and responsibilities to be assumed individually and collectively, and defining the content of a plan for immediate action; and

f) Monitoring and evaluation of results from the actions performed by each of the participating communities. This process of monitoring and evaluation was coordinated by various groups of community representatives and supervised regularly, both by the technical team and by the organizations that are members of the RCPP.

This exercise had the principal product of a diagnosis-document per community, which shows an in-depth analysis of the reality present in the community, as well as a set of proposals for solution, integrated into a community development plan for the short and medium term.

Having said that, in what refers to the practical application of the methodology of community diagnoses, in our case study, a first aspect of 
una radiografía de la realidad existente en la misma, así como un conjunto de propuestas de solución, integradas en un plan de desarrollo comunitario de corto y mediano plazo.

Ahora bien, en lo que se refiere a la aplicación práctica de la metodología de los diagnósticos comunitarios, en nuestro caso de estudio, un primer aspecto de importancia decisiva fue el referido a la selección de los coordinadores estatales y de las comunidades en las que éste se ejecutaría. Así pues, durante los meses de abril a julio de 2014, mediante acuerdo consensuado entre los directivos de las organizaciones integrantes de la RCPP, se realizaron ambas actividades. En el caso de los coordinadores estatales, la selección se hizo con base en un perfil en el que se ponderaron las capacidades de los candidatos, eligiéndose un coordinador por cada uno de los estados participantes.

Respecto a las comunidades, los criterios generales que se tomaron en cuenta para su selección, fueron los relativos a la existencia de un alto grado de participación a nivel comunitario y con la organización campesina adscrita a la RCPP, disposición a participar en procesos de planeación colectiva, que se tratara de comunidades de alta y muy alta marginación y con población migrante y, por último, que las autoridades locales estuvieran de acuerdo en apoyar el proceso de diagnóstico comunitario en su totalidad y mostraran disposición a impulsar el plan de desarrollo y los proyectos que la comunidad definiera por consenso.

La localización por municipio, organización campesina y según su composición étnica, de las comunidades seleccionadas, se muestra en el Cuadro 1.

Ahora bien, a pesar de que la selección de los coordinadores estatales y las comunidades participantes, así como la organización y realización de los diferentes talleres comunitarios, se apegó, en términos generales, a los requerimientos de la metodología de los diagnósticos participativos. Debemos reconocer que, durante la ejecución del proyecto, se presentaron diversos problemas de implementación, no previstos en la fase de planeación, entre los que sobresalen los que a continuación se indican, junto con la forma en que éstos fueron atendidos.

1. La localización de las comunidades, muy distantes entre sí, así como la ubicación del centro habitual de operaciones de las organizaciones en decisive importance referred to the selection of state and community coordinators where it would be executed. Thus, during the months of April to July 2014, through consensual agreement between the directors of the organizations that are members of the RCPP, both activities were performed. In the case of state coordinators, the selection was based on a profile used to analyze the capacities of the candidates, and electing a coordinator for each one of the participating states.

Concerning the communities, the general criteria that were taken into account for their selection were those relative to the existence of a high degree of participation at the community level, and with the peasant organization affiliated to the RCPP, willingness to participate in collective planning processes, that they are communities of high and very high marginalization and with migrant population, and lastly, that the local authorities agreed to support the community diagnosis process in its totality and showed a willingness to promote the development plan and the projects that the community defined through consensus.

The following table shows the location according to municipality, peasant organization and ethnic composition of the communities selected.

Having said that, even when the selection of the state coordinators and participating communities as well as the organization and performance of the different community workshops, was attached in general terms to the requirements of the methodology of participatory diagnoses. We must recognize that during the execution of the project, various implementation problems took place, which were unforeseen in the planning phase. Next, the ones that stood out are shown, together with the way in which they were addressed.

1. The location of the communities, very different between each other, as well as the location of the habitual operation center of the organizations where they are registered, represented a great challenge in the four states, which are diverse in their regional geography and suffer grave problems of communication and transport. This problem was overcome thanks to the effort and tenacity of state coordinators, as well as the technical support staff.

2. The legal regulations and usos y constumbres in the communities and ejidos indicate that transferring 
Cuadro 1. Comunidades participantes por municipio, organización campesina y composición étnica.

Table 1. Participating communities per municipality, peasant organization and ethnic composition.

\begin{tabular}{|c|c|c|c|c|}
\hline Estado & Municipio & Comunidad & Organización & $\begin{array}{c}\text { Composición étnica } \\
\text { mayoritaria }\end{array}$ \\
\hline \multirow{4}{*}{ Chihuahua } & Bocoyna & Repechique & $\mathrm{FDCCH}$ & Raramuri \\
\hline & Madera & Nahueriachi & $\mathrm{FDCCH}$ & Mestizo \\
\hline & Cuauhtémoc & Lázaro Cárdenas & FDCCH & Mestizo \\
\hline & Bachíniva & Manuel Ávila Camacho & FDCCH & Mestizo \\
\hline \multirow{5}{*}{ Oaxaca } & San Pedro Ocotepec & Santa Cruz Ocotal & Yeni Navan & Mixe \\
\hline & Santa María Lachixío & Santa María Lachixío & Centeotl & Zapoteco \\
\hline & Santa María Zacatepec & San Juan Cabeza de Río & Yeni Navan & Mixteco \\
\hline & San Miguel Huautla & Tierra Colorada & CEDICAM & Mixteco \\
\hline & Santa María Yucuhiti & Miramar & COPPFUMIR & Mixteco \\
\hline \multirow{6}{*}{ San Luis Potosí } & \multirow{6}{*}{ Xilitla } & Coronel José Castillo & COCIHP & Náhuatl \\
\hline & & Tlaletla & COCIHP & Náhuatl \\
\hline & & Pilateno & COCIHP & Náhuatl \\
\hline & & La Trinidad & COCIHP & Náhuatl \\
\hline & & Poxtla & COCIHP & Náhuatl \\
\hline & & Xilosuchico & COCIHP & Náhuatl \\
\hline \multirow{2}{*}{ Tabasco } & \multirow{2}{*}{ Balancán } & Miguel Hidalgo Sacaolas & Comunidad Fértil & Mestizo \\
\hline & & Arroyo El Triunfo $1^{\mathrm{a}}$ & Comunidad Fértil & Mestizo \\
\hline
\end{tabular}

Fuente: elaboración propia a partir de los resultados de la investigación realizada. Source: prepared by authors based on the results of the study performed.

las que se inscriben, representaron un gran desafío en los cuatro estados, que son diversos en su geografía regional y padecen graves problemas de comunicación y transporte. Este problema se logró superar gracias al esfuerzo y empeño de los coordinadores estatales, así como del personal de apoyo técnico.

2. La normatividad legal y por usos y costumbres de las comunidades y ejidos indican que los traspasos de cargos, se llevan a cabo de forma variable y flexible. Dependiendo de cada lugar y del cargo en cuestión, se realizan cambios de autoridades y comisiones cada tres años, un año o cuatro meses. Durante el período de ejecución del proyecto, esta circunstancia se presentó en la mayoría de las comunidades. Para atender dicho problema, lo que se hizo fue actualizar a los nuevos representantes en cuanto al acuerdo tomado por la comunidad, en el sentido de participar activamente en la realización de los diagnósticos comunitarios. De este modo, se les puso al tanto de las actividades ya ejecutadas y las previstas en el futuro inmediato, solicitándoles su participación y apoyo para no afectar el proceso y continuar con normalidad las actividades. En todos los casos, las nuevas autoridades y comisionados respaldaron y colaboraron de manera institucional con el mismo. Lo antes positions is done in a variable and flexible way. Depending on each place and the position in question, changes of authorities and commissions were made every three years, one year or four months. During the execution period of the project, this circumstance was present in most of the communities. To address this problem, what was done is to update the new representatives when it comes to the agreement made by the community, in the sense of participating actively in the performance of community diagnoses. Thus, they were informed about the activities already executed and those foreseen for the immediate future, requesting from them their participation and support in order not to affect the process and to continue the activities normally. In every case, the new authorities and commissioners endorsed and collaborated institutionally with it. This confirms the strength of the community democratic culture, since once an agreement was adopted it is possible to give it continuity, regardless of the changes in authorities that happen in the interim.

3. In the case of the state of San Luis Potosí, an important piece of data that should be highlighted is that each of the participating indigenous communities in the project are made 
anotado confirma la fuerza de la cultura democrática comunitaria, ya que, una vez adoptado un acuerdo, es posible darle continuidad, independientemente de los relevos de autoridades que se presenten en el inter.

3. En el caso del estado de San Luis Potosí, un dato importante que es necesario destacar es que cada una de las comunidades indígenas participantes en el proyecto están integradas por dos o más localidades, con sus propias demarcaciones subterritoriales, núcleos poblacionales y formas de organización básica para la gobernanza y atención de sus necesidades. Debido a lo anterior, fue indispensable que las actividades del diagnóstico tomaran en consideración a las 7 localidades de la comunidad de Tlaletla, las 2 de Pilateno, las 6 de Coronel José Castillo, las 8 de Poxtla, las 2 de La Trinidad y las 5 de Xilosuchico. De esta suerte, lograr contar con evaluaciones y propuestas de desarrollo en 30 localidades pertenecientes a las comunidades de referencia implicó emplear mayores esfuerzos y tiempo a los responsables del proyecto a nivel estatal, al equipo central de ERANDI y a los propios actores locales.

4. En algunas ocasiones, dificultades derivadas de falta de comunicación, periodos de alta actividad agrícola o festividades religiosas, provocaron la suspensión de algunos eventos, que tuvieron que ser reprogramados.

Antes de concluir este apartado, consideramos igualmente necesario señalar que la realización de las actividades contempladas en el proyecto contó también con algunos aspectos favorables, que posibilitaron el mejor cumplimiento de sus objetivos. Se trató básicamente de alianzas y complementariedades generadas con diversos actores, entre los que sobresalen, instituciones educativas de nivel medio superior y superior, una amplia gama de organizaciones de la sociedad civil, y diversas organizaciones y fundaciones de ámbito internacional.

\section{RESULTADOS}

Los resultados del estudio están organizados en tres partes. En la primera de ellas, se presentan los de orden técnico y metodológico, derivados de la ejecución del proyecto. En la segunda, se exhiben los principales problemas de carácter económico, político y up by two or more localities, with their own sub-territorial demarcations, population nuclei, and basic organizational forms for governance and attention to their needs. Due to this, it was essential for the activities of the diagnosis to take into consideration the 7 localities in the community of Tlaletla, 2 from Pilateno, 6 from Coronel José Castillo, 8 from Poxtla, 2 from La Trinidad, and 5 from Xilosuchico. With this, evaluations and proposals for development were available in 30 localities that belong to the communities of reference, which implied using greater efforts and time by those responsible for the project at the state level, the central team from ERANDI and the local actors themselves.

4. Sometimes, difficulties derived from the lack of communication, periods of high agricultural activity or religious festivities, provoked the suspension of some events, which had to be reprogrammed.

Before concluding this section, it is also necessary to point out that performing the activities contemplated in the project also had some favorable aspects, which made it possible to fulfill their objectives in the best manner. It was basically alliances and complementarities generated with various actors, among which educational institutions of upper intermediate and upper level, a broad range of civil society organizations, and various organizations and foundations of the international sphere stand out.

\section{RESULTS}

The study's results are organized into three parts. In the first of these, those of technical and methodological order are presented, derived from the execution of the project. In the second, the main problems of economic, political and organizational nature were exhibited, which were detected and which were common in at least 6 of the participating communities; and in the third part, the potentialities discovered were exposed as well as the future perspectives that open to these same communities.

\section{Technical-Methodological Results}

According to what was programmed, the workshops of community diagnosis and planning 
organizativo que se detectaron y que fueron comunes en, al menos, 6 de las comunidades participantes y, en la tercera parte, se exponen las potencialidades descubiertas y las perspectivas de futuro que se abren a estas mismas comunidades.

\section{Resultados de orden técnico-metodológico}

Conforme a lo programado, los talleres de diagnóstico y planeación comunitaria se realizaron a partir del mes de octubre de 2014 y hasta septiembre de 2015; sin embargo, el número de talleres y la cantidad de días empleados en cada comunidad fue variable, tal como se muestra en el Cuadro 2.

Cabe apuntar que, en este rubro, la meta original consistía en realizar tres talleres por comunidad (51 en total), de tal modo que los 69 finalmente realizados, superan en $26.08 \%$ dicha meta. Lo anterior se explica debido a que, en la práctica, el número de talleres efectuados dependió enteramente del interés y la disposición mostrada por los habitantes de cada una de éstas. Así, hubo comunidades como la were carried out starting in October 2014, and until September 2015; however, the number of workshops and the number of days used in each community was variable, as is shown in the following table.

It should be mentioned that, in this sphere, the original goal consisted in performing three workshops per community (51 in total), so that the 69 finally performed exceeded the goal by $26.08 \%$. This is explained because, in practice, the number of workshops carried out depended entirely on the interest and willingness shown by the inhabitants of each of these. Thus, there were communities such as Tlaletla, in the state of San Luis Potosí, where up to ten workshops were performed, and communities like Tierra Colorada or Miramar, in the state of Oaxaca, where only one workshop was organized, although the number of days used in both communities was one in the first case and 6 in the second.

When it comes to participants, in addition to the population in general, members of the existing structures for social representation participated in the different workshops, both of civil and agrarian

Cuadro 2. Total de talleres realizados por comunidad y por estado y cantidad de días empleados.

Table 2. Total of workshops carried out by community and by state and number of days used.

\begin{tabular}{llrr}
\hline \multirow{2}{*}{ Estado } & \multicolumn{1}{c}{ Comunidad } & Número de talleres & Número días empleados \\
& Nahuérachi & 3 & 5 \\
Chihuahua & Repechique & 3 & 5 \\
& Manuel Ávila Camacho & 3 & 4 \\
& Lázaro Cárdenas & 3 & 4 \\
\hline Subtotal & & 12 & 6 \\
& Miramar & 1 & 10 \\
Oaxaca & Santa Cruz Ocotal & 5 & 6 \\
& San Juan Cabeza de Río & 3 & 8 \\
& Santa Maria Lachixío & 5 & 1 \\
\hline Subtotal & Tierra Colorada & 1 & 31 \\
& & 15 & 10 \\
San Luis Potosí & Tlaletla & 10 & 6 \\
& Pilateno & 4 & 9 \\
& Coronel José Castillo & 8 & 7 \\
\hline Subtotal & Poxtla & 7 & 3 \\
\hline Tabasco & La Trinidad & 3 & 3 \\
\hline Subtotal & Xilosuchico & 3 & 38 \\
\hline
\end{tabular}

Fuente: elaboración propia a partir de los resultados de la investigación realizada. \& Source: prepared by authors based on results from the study performed. 
de Tlaletla, en el estado de San Luis Potosí, en la que se realizaron hasta diez talleres y, comunidades como Tierra Colorada o Miramar, en el estado de Oaxaca, en las que sólo se organizó un taller, si bien el número de días empleados en ambas comunidades fue de 1 , en el primer caso y de 6 en el segundo.

En cuanto a los participantes, además de la población en general, en los diferentes talleres participaron los integrantes de las estructuras de representación social existentes, tanto las de carácter civil como las de tipo agrario. Entre las autoridades de carácter civil se encuentran: presidentes; agentes o delegados municipales; jueces auxiliares; representantes de diversos comités de obras o servicios comunitarios: de educación, salud, caminos, electrificación, vivienda, agua, camposanto, etcétera, y comités ciudadanos que sirven para la canalización de apoyos o subsidios gubernamentales a zonas rurales marginadas. Entre las autoridades locales de tipo agrario, se encuentran los comisariados y los consejos de vigilancia, ya sean ejidales o comunales.

Junto a lo anterior, cabe destacar que, en mayor o menor medida, en todos los eventos de diagnóstico comunitario, participaron las personas que cuentan con un alto grado de reconocimiento al interior de su comunidad, ya sea por haber cumplido con sus responsabilidades al frente de su encargo, o por la experiencia, sabiduría y conocimiento de la historia de su pueblo.

Por último, se logró involucrar a otros actores sociales organizados que coexisten dentro de cada comunidad, como lo son: grupos de mujeres, cooperativas de ahorro y préstamo, cooperativas de productores de café, maíz, frijol, amaranto y asociaciones civiles de diverso tipo. De esta manera, dependiendo de la complejidad y nivel de desarrollo organizativo, el número de participantes en cada comunidad, fue muy variado; pero, en todos los casos, altamente representativo.

Las cifras relativas al número de participantes directos y de beneficiarios indirectos y por ende el impacto a nivel comunitario de los talleres realizados, pueden observarse en el Cuadro 3.

Cabe aclarar que para determinar el número de participantes directos hemos tomado como referencia, la cantidad más grande de participantes por evento en cada una de las comunidades involucradas en el proyecto, tomando en cuenta que a los distintos talleres normalmente asistían las mismas personas. $\mathrm{La}$ character. Among the civil authoritier, there are: presidents; municipal agents or delegates; auxiliary judges; representatives of various committees of works or community services: education, health, paths, electricity, housing, water, churchyard, etc., and citizen committees that serve to channel government backing or subsidies to marginalized rural zones. Among the agrarian local authorities, there are commissaries and vigilance councils, whether from ejidos or communal.

Together with this, it should be mentioned that, to a greater or lesser degree, people who have a high level of recognition inside their community participated in all the events of community diagnosis, whether from having fulfilled their responsibilities in face of their charge, or from the experience, wisdom and knowledge of their people's history.

Lastly, it was possible to involve other organized social actors that coexist within each community, such as: groups of women, savings and loans cooperatives, coffee producing cooperatives, maize, bean, amaranth and civil associations of different types. Therefore, depending on the complexity and level of organizational development, the number of participants in each community was quite varied, although in every case highly representative.

The figures related to the number of direct participants and indirect beneficiaries, and therefore the impact at the community level of the workshops performed, can be observed in the next table.

It should be clarified that in order to determine the number of direct participants we have taken as reference, the largest amount of participants per event in each of the communities involved in the project, taking into account that normally the same people attended the different workshops. The indirectly benefitted population is the result of multiplying the direct participants by five, considering that this figure corresponds to the number of members of a typical peasant family. Thus, in the four states, the average community impact compared to the total population was $6.1 \%$, if only direct participants are taken into consideration, and $30.6 \%$ if the indirect are included.

Regarding the gender composition of participants in the workshops, it presented a relative equilibrium, as shown in the following table.

Finally, it should be highlighted that the activities of monitoring carried out until the first semester of 2017 have allowed observing that in the different 
Cuadro 3. Porcentaje de participantes directos e indirectos en los talleres de planeación comunitaria con respecto a la población total de las comunidades participantes por estado.

Table 3. Percentage of direct and indirect participants in the community planning workshops with regard to the total population of the participating communities by state.

\begin{tabular}{lccccccc}
\hline \multicolumn{1}{c}{ Estado } & $\begin{array}{c}\text { No. de } \\
\text { Municipios }\end{array}$ & $\begin{array}{c}\text { No. de } \\
\text { comunidades }\end{array}$ & $\begin{array}{c}\text { Población total en } \\
\text { las comunidades }\end{array}$ & $\begin{array}{c}\text { Participantes } \\
\text { directos }\end{array}$ & $\begin{array}{c}\text { Participantes } \\
\text { indirectos }\end{array}$ & $\begin{array}{c}\text { \%participantes } \\
\text { directos/pobla-ción indirectos/población } \\
\text { de la comunidad } \\
\text { de la comunidad }\end{array}$ \\
\hline Chihuahua & 4 & 4 & 2478 & 118 & 590 & 4.7 & 23.8 \\
Oaxaca & 5 & 5 & 3515 & 241 & 1205 & 6.8 & 34.2 \\
San Luis Potosí & 1 & 6 & 5757 & 335 & 1675 & 5.8 & 29.0 \\
Tabasco & 1 & 2 & 1147 & 97 & 485 & 8.4 & 42.2 \\
\hline Totales y promedios & 11 & 17 & 12897 & 791 & 3955 & 6.1 & 30.6 \\
\hline
\end{tabular}

Fuente: elaboración propia a partir de los resultados de la investigación realizada. \& Source: prepared by authors based on the results from the research performed.

población beneficiaria indirectamente es el resultado de multiplicar por cinco a los participantes directos, considerando que dicha cifra corresponde con el número de integrantes de una familia campesina típica. De esta suerte, en los cuatro estados, el impacto comunitario promedio, con respecto a la población total, fue de $6.1 \%$, si se considera únicamente a los participantes directos y, de $30.6 \%$, si se incluye a los indirectos.

En lo que respecta a la composición de género de los participantes en los talleres, ésta presentó un relativo equilibrio, tal como se muestra en el Cuadro 4.

Finalmente, cabe destacar que las actividades de seguimiento realizadas hasta el primer semestre de 2017, han permitido observar que en las distintas comunidades participantes, se han conformado y empezado a operar distintos grupos y comisiones de trabajo, los cuales han venido realizando, con mayor o menor profundidad y amplitud, las siguientes acciones: a) impulso de campañas de difusión de los resultados y hallazgos del proceso de planeación participativa en toda la comunidad, priorizando aquellos participating communities, different groups and working commissions have been established and begun operating. They have performed, with more or less depth and amplitude, the following actions: a) promotion of dissemination campaigns of the results and findings from the participatory planning process in the whole community, prioritizing those groups, sectors or families that had not participated in the different phases of community diagnosis; b) impact and management in face of municipal authorities to channel supports of different kind to various productive projects; and c) dissemination of diagnosis results to neighboring communities with the purpose of opening new possibilities of intercommunity collaboration and keeping active the policy of relations and complementarity with allied organizations and institutions.

\section{Main Problems Detected}

A list, neither thorough nor limiting, of common problems present in the different communities

Cuadro 4. Total de participantes (hombres y mujeres) por estado.

Table 4. Total of participants (men and women) by state.

\begin{tabular}{lccccc}
\hline \multicolumn{1}{c}{ Estado } & Mujeres & $\%$ & Hombres & $\%$ & Total \\
\hline Chihuahua & 60 & 51 & 58 & 49 & 118 \\
Oaxaca & 106 & 44 & 135 & 56 & 241 \\
San Luis Potosí & 130 & 39 & 205 & 61 & 335 \\
Tabasco & 53 & 55 & 44 & 45 & 97 \\
\hline Total & 349 & 44 & 442 & 56 & 791 \\
\hline
\end{tabular}

Fuente: elaboración propia a partir de los resultados de la investigación realizada. \& Source: prepared by authors based on the results from the study performed. 
grupos, sectores o familias que no hubiesen participado en las distintas fases del diagnóstico comunitario; b) incidencia y gestión ante las autoridades municipales para canalizar apoyos de distinta índole a diversos proyectos productivos, y c) difusión de los resultados del diagnóstico a las comunidades vecinas con el propósito de abrir nuevas posibilidades de colaboración intercomunitaria y mantener activa la política de relaciones y complementariedad con las organizaciones e instituciones aliadas.

\section{Principales problemas detectados}

Una enumeración no exhaustiva ni limitativa de los problemas comunes presentes en las diferentes comunidades, consideradas dentro del universo del presente proyecto, comprendería los siguientes:

1. Falta de conocimiento de los límites territoriales de la comunidad y conflictos agrarios con comunidades limítrofes. Este problema se detectó principalmente en diversas comunidades del estado de Oaxaca.

2. Desconocimiento de los recursos naturales de la comunidad. A título de ejemplo, se destaca aquí el caso de la comunidad de Santa María Lachixio, Oaxaca, en donde previo a la realización de los talleres de planeación comunitaria, sus habitantes desconocían a quien correspondía el manejo de las 5000 hectáreas de bosque con que cuenta la comunidad. Así que, sólo después de largas deliberaciones y como resultado de la revisión de diversos documentos, se pudo llegar a la conclusión de que dicha prerrogativa corresponde a ésta y no al Ayuntamiento, como muchos creían.

3. Carencias sensibles en infraestructura urbana básica en prácticamente todas las comunidades incluidas en la cobertura del presente proyecto.

4. Presión creciente hacia la migración forzada de la población por razones económicas. En relación con este problema se presentan dos situaciones contrastantes. En el caso de las comunidades cafetaleras del estado de Oaxaca, el incremento de la migración observado en los últimos años, obedece a la caída del empleo y los ingresos derivados del cultivo del café, que se vio seriamente afectado por la plaga de la roya. En cambio, en las comunidades mestizas del estado de Chihuahua, la migración, hacia los Estados Unidos, se da como considered within the universe of this study, would include the following:

1. Lack of knowledge of the territorial limits of the community and agrarian conflicts with adjacent communities. This problem was detected mainly in various communities of the state of Oaxaca.

2. Lack of awareness of the natural resources of the community. The case of the community of Santa María Lachixio, Oaxaca, stands out as an example, where before performing the community planning workshops, inhabitants ignored who was in charge of the management of the 5,000 hectares of forest that belong to the community. Thus, only after long deliberations and as a result of the review of various documents, the conclusion was reached that such prerogative corresponds to the community and not to the Town Council, as many believed.

3. Sensitive scarcity in basic urban infrastructure in practically all the communities included in the coverage of this project.

4. Growing pressure toward forced migration of the population due to economic reasons. In relation to this problem, two contrasting situations emerge. In the case of the coffee producing communities of the state of Oaxaca, the increase in migration observed in recent years responds to the decrease in employment and income derived from coffee growing, which was seriously affected by the blight pest. In contrast, in the mestizo communities of the state of Chihuahua, migration toward the United States takes place as part of the processes of social and economic reproduction of those human centers. This is a cyclical phenomenon that the communities have been learning to use to their benefit and where participatory planning has been incentivized and strengthened, as a positive trend.

5. Significant backwardness in indicators of social welfare. In all the communities studied, grave scarcity was detected in matters of education, health and housing; however, as extreme case, it was confirmed that in the community of Repechique, Chihuahua, numerous families suffer from hunger in certain seasons of the year.

6. Persistence of machismo culture and gender discrimination. In most of the communities, the women participate in farming tasks, but they do 
parte de los propios procesos de reproducción social y económica de dichos núcleos humanos. Se trata de un fenómeno cíclico que las comunidades han venido aprendiendo a usar en su beneficio y que, como tendencia positiva, la planificación participativa ha incentivado y fortalecido.

5. Rezago significativo en indicadores de bienestar social. En todas las comunidades estudiadas, se detectaron carencias graves en materia de educación, salud y vivienda; sin embargo, como caso extremo, se constató que en la comunidad de Repechique, Chihuahua, en ciertas épocas del año, numerosas familias padecen hambre.

6. Persistencia de la cultura machista y la discriminación de género. En la mayoría de las comunidades, las mujeres participan en las labores del campo, pero no reciben remuneración alguna por su trabajo, amén de que, en muy pocos casos, tienen acceso a la propiedad de la tierra. Su participación en las asambleas comunitarias es escasa, casi no se toman en cuenta sus opiniones y sólo en casos muy aislados asumen cargos de representación social.

7. Exceso de figuras asociativas en algunas comunidades que compiten entre sí. Por ejemplo, en la comunidad de Santa Cruz Ocotal, ubicada en la región mixe del estado de Oaxaca, a pesar del relativo aislamiento que presenta, se detectó que en su interior participan hasta cuatro organizaciones distintas de productores que se dedican a la producción y comercialización de café orgánico, debidamente certificado para exportar. Este fraccionalismo organizativo provoca una fuerte dispersión de recursos y esfuerzos que bien podrían ser aprovechados para emprender proyectos de mayor envergadura y de beneficio generalizado para los socios de las cuatro organizaciones, como podrían ser la atención a la plaga de la roya, disponer de infraestructura de uso común para el beneficiado seco y acceder a programas de capacitación y financiamiento.

\section{Potencialidades descubiertas}

Entre las potencialidades descubiertas, destaca, en primer lugar, la posibilidad real de activar y potenciar el capital social ${ }^{5}$ existente en las comunidades. Esto debido a que el proceso de análisis de la información, sobretodo, la que recopila la comunidad, brinda un panorama más completo de lo que se tiene y de lo not receive any pay for their work, and also only in few cases do they have access to land ownership. Their participation in community assemblies is scarce, their opinions are almost never taken into account, and only on quite isolated cases do they take on positions of social representation.

7. Excess of associative figures in some communities that compete against each other. For example, in the community of Santa Cruz Ocotal, located in the Mixe region of the state of Oaxaca, despite the relative isolation it presents, it was detected that up to four different organizations of producers participate in the region that are devoted to the production and commercialization of organic coffee, duly certified for exporting. This organizational fractioning provokes a strong dispersal of resources and efforts that could well be used to set up larger projects and with generalized benefit for the members of the four organizations, such as attention to the blight pest, having infrastructure of common use for dry processing, and gaining access to training and financing programs.

\section{Potentialities Uncovered}

Among the potentialities uncovered, the first that stands out is the real possibility of activating and potentiating the existing social capital ${ }^{3}$ in the communities. This is because the information analysis process, particularly of the information gathered by the community, provides a more complete panorama of what there is and what can be done. This collective reflection provides trust, in different degrees, and strengthens internal unity, reactivating the social fabric and stimulating the associative nature. Based on this, it is not exaggerated to say that the 17 communities that have participated in this project are now better trained, from the organizational point of view, to resist demobilization and the political and ideological manipulation that cronyism and the welfare approach prevalent in rural areas of the country has traditionally generated.

In the second place, it is significant to note that practically all the communities have abundant natural resources and numerous "white elephants" that have not been operating for lack of budget, appropriate technology, technical training, and qualified staff. 
que se puede hacer. Dicha reflexión colectiva, proporciona, en diversos grados, confianza y fortalece la unidad interna, reactivando el tejido social y estimulando la asociatividad. Con base en lo anterior, no resulta exagerado afirmar que las 17 comunidades que han participado en este proyecto están ahora mejor capacitadas, desde el punto de vista organizacional, para resistir a la desmovilización y manipulación política e ideológica que tradicionalmente ha generado el clientelismo y el asistencialismo prevalecientes en el medio rural del país.

En segundo lugar, resulta significativo hacer notar que prácticamente todas las comunidades disponen de abundantes recursos naturales y de numerosos "elefantes blancos" que no se han puesto a operar por falta de presupuesto, tecnología apropiada, capacitación técnica y personal calificado.

Asimismo, en todas las comunidades participantes se detectó la existencia de distintas prácticas de trabajo colectivo voluntario, no remunerado (tequio, faenas, mano vuelta, etcétera), que representa un activo intangible que posibilita que la comunidad rural actúe como una poderosa institución social que puede brindar respaldo a sus distintos pobladores en casos de premura económica, social o ambiental.

Otro aspecto a destacar es que, tanto en el estado de Chihuahua como en el de San Luis Potosí, el trabajo de diagnóstico comunitario participativo se ha vinculado, de manera natural, con la lucha por la defensa del territorio, en contra de megaproyectos que atentan contra la biodiversidad y el equilibrio ecológico. Específicamente en el caso de Chihuahua se lucha en contra de la instalación de un gasoducto y de la construcción del aeropuerto de Creel, en tanto que, en San Luis Potosí, la lucha se encamina en contra del acueducto con el que se pretende desviar parte del agua de la cuenca del Río Pánuco hacia Nuevo León (Proyecto Monterrey VI) y la práctica del fracking en la actividad minera.

Cabe destacar, por último, que los resultados del presente estudio son, en términos generales, similares a los alcanzados por otros trabajos realizados recientemente en México, particularmente los de Negrete y Bocco, 2003; García Batíz, 2006; Terrones Cordero, 2013.

\section{CONCLUSIONES}

Con base en los resultados antes expuestos, podemos concluir que la metodología de los diagnósticos comunitarios participativos ha confirmado su
Likewise, in all the participating communities, the existence of different practices of collective, unpaid (tequio, faenas, mano vuelta, etc.), voluntary work was detected, representing an intangible asset that makes it possible for the rural community to act as a powerful social institution that can provide support to its different inhabitants in cases of economic, social or environmental urgency.

Another aspect to highlight is that, both in the state of Chihuahua and in San Luis Potosí, the work for participatory community diagnosis has been linked, in a natural way, with the struggle over defense of the territory, against megaprojects that threaten biodiversity and ecological equilibrium. Specifically, in the case of Chihuahua, there is a struggle against the installation of a gas pipeline and the construction of the airport in Creel, while in San Luis Potosí, the struggle is directed against the aqueduct which is planned to divert part of the water from the Pánuco River watershed toward the state of Nuevo León (Proyecto Monterrey VI) and against the practice of fracking in mining.

Lastly, it should be highlighted that the results from this study are, in general terms, similar to those reached by other studies recently performed in Mexico, particularly those by Negrete and Bocco (2003), García Batíz (2006), and Terrones Cordero (2013).

\section{CONCLUSIONS}

Based on the results presented above, we can conclude that the methodology of participatory community diagnoses have confirmed their technical validity, since they have evidenced that inhabitants of rural communities of the country are entirely capable of participating in democratic planning processes of their own development. This statement is sustained on the significant degree of appropriation of the methodology by the participants, which includes the community, agrarian and civil authorities, who have backed this type of initiatives, when convinced that it is a way of community empowerment that allows having a shared project of the future, which emerged from the contest and the contributions of all and whose materialization requires equally the participation of different sectors and groups that constitute the rural communities. In this order of ideas, the future project represents for their managers 
validez técnica, en tanto ha puesto en evidencia que los habitantes de las comunidades rurales del país son enteramente capaces de participar en procesos de planeación democrática de su propio desarrollo. La afirmación anterior se sustenta en el significativo grado de apropiación de la metodología por parte de los participantes, lo cual incluye a las autoridades comunitarias, agrarias y civiles, quienes han respaldado este tipo de iniciativas, al convencerse de que se trata de una forma de empoderamiento comunitario, que permite disponer de un proyecto compartido de futuro, nacido del concurso y las aportaciones de todos y cuya materialización requiere igualmente la participación de los diferentes sectores y grupos que constituyen las comunidades rurales. En este orden de ideas, el proyecto de futuro representa para sus gestores la posibilidad de hacer de la vida comunitaria una realidad de mayor justicia, solidaridad, equidad y sustentabilidad, en la medida en que se basa en el reconocimiento, respeto y promoción de los derechos ciudadanos en los ámbitos de lo civil, lo social, lo económico, lo político, lo cultural y lo ambiental.

La experiencia de los diagnósticos comunitarios realizados demuestra que, a la par en que éste se va elaborando, se está integrando y fortaleciendo un grupo como sujeto colectivo que asume el compromiso de llevarlo a cabo. Así, la construcción del actor social y del proyecto de futuro, forman parte de un mismo proceso de desarrollo social endógeno.

De igual manera, se ha confirmado que ninguno de los problemas detectados en las diferentes comunidades se da en forma aislada, sino que forma parte de una serie de interacciones complejas. Por tal motivo, bien se puede afirmar que cada problema es multidimensional y multifactorial. Por ejemplo, la desnutrición de la población rural, tiene que ver, en primera instancia, con la producción de alimentos, sus costos y modos de venta. Pero también está relacionada con cuestiones ambientales como la cantidad y calidad del agua disponible e, incluso, con aspectos culturales como las costumbres familiares y comunitarias o las modas impuestas por la publicidad comercial sobre tipos de alimentos poco saludables $\mathrm{y}$, finalmente, se vincula igualmente con temas políticos como los objetivos y prioridades de los programas gubernamentales de desarrollo rural y de combate al hambre, actualmente vigentes. Atendiendo a esta circunstancia, se han detectado los problemas que pueden considerarse como centrales en las diferentes comunidades, en la medida en que son the possibility of making community life a reality of greater justice, solidarity, equity and sustainability, to the degree that it is based on the recognition, respect and promotion of citizen rights in the civil, social, economic, political, cultural, and environmental spheres.

The experience of the community diagnoses performed show that, at the same time that it was elaborated, a group was becoming integrated and strengthened as a collective subject that assumes the commitment of implementing it. Thus, the construction of the social actor and the future project is part of the same process of endogenous social development.

Likewise, it has been confirmed that none of the problems detected in the different communities takes place in an isolated manner, but rather that it is part of a series of complex interactions. For this reason, it can be said that each problem is multidimensional and multifactorial. For example, malnutrition of the rural population is related, in first instance, with the production of foods, their costs and selling modes. However, it is also related with environmental issues such as the quantity and quality of the water available, and even with cultural aspects such as family and community customs or fashions imposed by commercial advertising about unhealthy foods and, finally, equally linked to policy issues such as objectives and priorities of government programs for rural development and fighting hunger that are currently in force. Addressing this circumstance, problems have been detected that can be considered as central in the different communities, to the extent that they are felt and recognized by a large sector of these and which, therefore, have the possibility of causing the interest of many people in their possible solution.

Based on what was mentioned before, it can be said that the application of the participatory diagnosis methodology allowed for participating communities in this project to move from a situation of relative passivity to one of organized action, based on a concrete plan for activities, defined collectively. In this sense, the most important products derived from participatory planning were the documents of community diagnosis and of the local development plan, which at the same time allowed coordinating and directing the changing actions which, otherwise, could not have been carried out. 
sentidos y reconocidos por un gran sector de éstas y que, por ende, tienen la posibilidad de suscitar el interés de muchas personas en su eventual solución.

Con base en los antes indicado, se puede afirmar que la aplicación de la metodología de los diagnósticos participativos, permitió que las comunidades participantes en este proyecto, pasaran de una situación de relativa pasividad a otra de acción organizada, en base a un plan concreto de actividades, definido colectivamente. En este sentido, los productos más importantes derivados de la planeación participativa fueron los documentos de diagnóstico comunitario y de plan de desarrollo local, mismos que, a su vez, permitieron coordinar y orientar las acciones de cambio que, de otra manera, no se hubieran podido llevar a cabo.

No obstante, debemos también reconocer que la metodología de los diagnósticos comunitarios tiene un alcance limitado al entorno inmediato de la comunidad, así como a la vida cotidiana de sus habitantes, en tanto que su impacto sobre variables o fenómenos macro económicos y socio políticos más amplios, como la migración, la práctica del fracking en la industria minero-extractiva o el despojo del agua a las comunidades, es mucho menor. Por esta razón, es fundamental que una vez concluido el proceso de planeación comunitaria, esté se complemente con acciones estratégicas en el campo de la capacitación organizacional y empresarial, en lo relativo a la gestión de recursos financieros y en la búsqueda de alianzas regionales con otras comunidades con problemáticas similares.

En síntesis, los procesos de planeación participativa, en la medida en que refuerzan la identidad colectiva de los participantes y ofrecen nuevas oportunidades de empleo y generación de ingresos, no visualizadas ni detectadas con anterioridad, constituyen una de las herramientas técnico-sociales de mayor utilidad para la conversión de las comunidades rurales en actores sociales con proyecto propio y capacidad organizacional para gestionar adecuadamente sus recursos, evitando de este modo caer en la tragedia de los comunes. La afirmación anterior se sustenta en los impactos socio-culturales y económicos que genera en las comunidades en las que tiene lugar y que, de manera resumida, se sintetizan en lo siguiente: activación y potenciación del capital social existente, fortalecimiento de la organización productiva, generación de un compromiso colectivo que involucra a
However, we should also recognize that the methodology of community diagnosis has a reach limited to the immediate environment of the community, as well as the daily life of their inhabitants, while its impact on broader macroeconomic and sociopolitical variables or phenomena, such as migration, the practice of fracking in the miningextractive industry or the plunder of water from the communities, is much lower. For this reason, it is fundamental that once the community planning process concludes, it is complemented with strategic actions in the field of organizational and entrepreneurial training, regarding the management of financial resources and the search for regional alliances with other communities with similar problems.

In sum, as long as participatory planning processes reinforce the collective identity of participants and offer new employment opportunities and income generation, which were not visualized or detected before, they constitute one of the most useful technical-social tools for the conversion of rural communities into social actors with a project of their own and organizational capacity to adequately manage their resources, thus avoiding falling into the tragedy of the commons. This statement is sustained on the socio-cultural and economic impacts generated in the communities where they take place, which in sum are synthesized in the following: activation and potentiation of the existing social capital, strengthening of the productive organization, generation of a collective commitment that involves vast sectors of the human center, broadening the awareness of their potentialities, identification of possibilities of improvement in their economic activity, and increase of the threshold of collective aspirations.

From the technical-operative angle and based on the experience of the execution of this project, we recommend that in future applications of this methodology, as part of the immersion process in the study region, field visits should be carried out in the communities selected with the aim of verifying on the field various aspects of logistical and cultural order, such as the existing distance between one and another, the available means of transport, and the main existing traditions (holidays, religious festivities, etc.), among other aspects of interest that should to be taken into account for an adequate planning of 
vastos sectores del núcleo humano, ampliación de la conciencia de sus potencialidades, identificación de posibilidades de mejora en su actividad económica, e incremento del umbral de las aspiraciones colectivas.

Desde un ángulo técnico-operativo y con base en la experiencia de ejecución del presente proyecto, nos permitimos recomendar que en futuras aplicaciones de esta metodología, como parte del proceso de inmersión en la región de estudio, se realicen recorridos de campo en las comunidades seleccionadas con la finalidad de verificar sobre terreno diversos aspectos de orden logístico y cultural, tales como la distancia existente entre unas y otras, los medios de transporte disponibles y las principales tradiciones existentes (días festivos, fiestas religiosas, etcétera), entre otros aspectos de interés, que deben tomarse en cuenta para una adecuada planeación del proyecto. Consecuentemente, se sugiere contar siempre con un cierto margen de tiempo -días de trabajo de campo adicionales- a fin de hacer frente a problemas no previstos y, sobre todo, evitar forzar o apresurar los procesos de asimilación y retroalimentación de la metodología por parte de las comunidades.

En el campo de la investigación, estimamos como posibles líneas de continuidad la realización, por una parte, de un estudio de monitoreo y seguimiento sobre los resultados que en los próximos años se vayan generando en las 17 comunidades que participaron en este proyecto, de tal modo que sea posible identificar y evaluar las variables que intervienen en el proceso de implementación de los planes de desarrollo comunitario y, en su caso, incorporar los ajustes y correcciones que resulten pertinentes y, por la otra, la realización de estudios similares al aquí expuesto, en diferentes estados del país, con el propósito de contar con mayor información empírica que permita enriquecer o ajustar la metodología en aquellos componentes que así lo requieran.

\section{NOTAS}

${ }^{1}$ En 1968, Garret Hardin al publicar su célebre artículo intitulado: The Tragedy of the commons, puso de manifiesto una situación en la que se degrada un recurso escaso que es utilizado en forma colectiva e intensiva, sin que nadie asuma los costos de su mantenimiento. En tales condiciones, al prevalecer la libertad de acceso a los recursos de uso común (RUC) y tomando en cuenta que cada productor persigue the project. Consequently, it is suggested to always have a certain margin of time -additional field work days- in order to face unforeseen problems and, above all, to avoid forcing or rushing the assimilation processes and feedback about the methodology from the communities.

In the research field, we estimate as possible lines of continuity, on the one hand, performing a study to monitor and follow-up on the results that will be generated in the next year in the 17 communities that participated in this project, so that it is possible to identify and evaluate the variables that intervene in the implementation process of community development plans, and in this case, incorporate the adjustments and corrections that are pertinent. On the other hand, performing similar studies to the one presented here, in different states of the country, with the purpose of having more empirical information that allows enrichening and/or adjusting the methodology in those components that so require.

\section{- End of the English version-

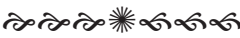

su propio beneficio inmediato, el destino final de dichos recursos no puede ser otro que su eventual destrucción, convirtiéndose así en una tragedia para sus poseedores originales. Como puede apreciarse, la tesis de la tragedia de los comunes, está basada en el supuesto de que los participantes son incapaces de conciliar sus intereses individuales, hacer valer sus decisiones y, consecuentemente, coordinar sus acciones, por lo cual se requiere la intervención de un agente externo que garantice la preservación de los RUC, ya sea que se trate del Estado o de la iniciativa privada. En sentido opuesto a esta tesis, Elinor Ostrom (2000), desarrolló una teoría de la acción colectiva que permite identificar las variables clave que pueden mejorar las capacidades de los individuos para resolver los problemas derivados de la adecuada gestión de los RUC, centrada en la creación de instituciones que permitan a los individuos alcanzar resultados productivos mutuamente beneficiosos, en circunstancias en las que las tentaciones de actuar como "gorrón" o de rehuir responsabilidades, puedan minimizarse. In 1968, Garret Hardin in his famous article titled "The Tragedy of the Commons" exposed a situation where a scarce resource that is used collectively and 
intensively is degraded without anyone assuming its maintenance costs. Under such conditions, when liberty of access to common use resources (CUR) prevails, and taking into account that each producer seeks his/her own immediate benefit, the final destination of such resources cannot be something other than their possible destruction, thus making this a tragedy for their original owners. As can be appreciated, the thesis of the tragedy of the commons is based on the assumption that the participants are incapable of reconciling their individual interests, asserting their decisions, and, consequently, coordinating their actions which is why the intervention of an external agent that ensures the preservation of the CUR is required, whether it is the State or private sector. In the opposite sense to this thesis, Elinor Ostrom (2000) developed a theory of collective action that allows identifying the key variables that can improve the abilities of individuals to solve problems derived from the adequate management of the CUR, centered on the creation of institutions that allow individuals to reach mutually beneficial productive results, under circumstances where the temptations of acting as "freeloader" or avoiding responsibilities, can be minimized.

${ }^{2}$ Como explican Osorio Rosales y Contreras Hernández (2009), en la génesis del Método del Diagnóstico Rural Participativo se reconoce una primera etapa en la que éste nace, a finales de los años setenta del siglo pasado, sobre todo en el mundo anglosajón, como Diagnóstico Rural Rápido, centrado básicamente en el conocimiento local técnico y rápido de la estructura agraria prevaleciente en las comunidades estudiadas. Hacia finales de la década de los ochenta, la gama de temas se amplía, incluyendo los más diversos aspectos de la vida rural y campesina y, de la misma forma, la rapidez del proceso deja de ser primordial, poniéndose el acento en la calidad y el grado de confianza alcanzado entre los agentes externos y la población local, adquiriendo su denominación actual. As Osorio Rosales and Contreras Hernández (2009) explain, in the genesis of the Participatory Rural Diagnosis Method a first stage is recognized where it emerges, at the end of the 1970s, particularly in English-speaking countries, as Fast Rural Diagnosis, centered basically on the local and fast technical understanding of the prevalent agrarian structure of the communities studied. Toward the end of the 1980s, the range of themes expanded, including the most diverse aspects of rural and peasant life and, similarly, the speed of the process ceases to be primordial, placing the accent in the quality and degree of trust reached between external agents and the local population, acquiring their current denomination.

3Para el politólogo norteamericano Robert Putnam (1994: 212), "el capital social se refiere a las características de organización social, tales como la confianza, las normas y redes que pueden mejorar la eficiencia de la sociedad mediante la facilitación de acciones coordinadas". * For the North American political scientist Robert Putnam (1994: 212), "social capital refers to the characteristics of social organizations, such as the trust, norms and networks that can improve the efficiency of society through easing coordinated actions".

\section{LITERATURA CITADA}

ACNUR (Alto Comisionado de las Naciones Unidas para los Refugiados). 2006. La herramienta del ACNUR para el Diagnóstico Participativo en las Operaciones, Ginebra. http:// www.who.int/mental_health/emergencies/participatory_assessment_spanish.pdf, consultado el 26 de agosto de 2016.

Chambers, Robert. 1997. Whose Reality Counts? Putting the First Last, London, ITDG.

Chevalier, Jaques, and Buckles, Daniel. 2009. SAS2 Guía para la Investigación Colaborativa y la Movilización Social, Ottawa, http://web.idrc.ca/openebooks/419-2/, consultado el 9 de julio de 2016.

CONAFOR (Comisión Nacional Forestal). 2014. Diagnóstico Participativo. Métodos e instrumentos para realizar el diagnóstico participativo comunitario, México, Secretaría del Medio Ambiente y Recursos Naturales.

FAO (Organización para la Alimentación y la Agricultura). 2008. Diagnóstico Rural Participativo y Planificación Comunitaria, Managua, FAO and NSFOP/UNICAM.

García Batíz, María Luisa. 2006. Planeación participativa: La experiencia de la política ambiental en México, México, Plaza y Valdés.

Geilfus, Frans. 80 herramientas para el desarrollo participativo: diagnóstico, planificación, monitoreo, evaluación, México, IICA.

Hardin, Garrett. 1968. The Tragedy of the Commons. Science, New Series, Vol. 162, No. 3859, pp: 1243-1248.

Herwer, Karl and Steiner, Kurt. 2002. Monitoreo y valoración del impacto. Instrumentos a usar en proyectos de desarrollo rural con un enfoque en el manejo sostenible de la tierra, Volumen 1, Berna. http://www.bvsde.paho.org/bbsacd/CD11/ monitoreo.pdf, consultado el 18 de septiembre de 2016.

Negrete Fernández, Gerardo, y Bocco Verdinelli, Gerardo. 2003. El ordenamiento ecológico comunitario: una alternativa de planeación participativa en el contexto de la política ambiental de México. In: Gaceta Ecológica, No. 68.

Osorio Rosales, María Luisa, y Contreras Hernández, Armando. 209. El diagnóstico rural participativo y el manejo de los 
recursos naturales. Revista Estudios Agrarios. Número 42, septiembre-diciembre. pp: 109-136.

Ostrom, Elinor. 2000. El gobierno de los bienes comunes, la evolución de las instituciones de acción colectiva, México, Fondo de Cultura económica. Traductoras: Corina Yturbe y Adriana Sandoval. 395 p.

Putnam, Robert. 1994. Para que la democracia funcione, Caracas, GALAC.

Quadri de la Torre, Gabriel. 2006. Políticas públicas: sustentabilidad y medio ambiente, México, Editorial Porrúa.

Terrones Cordero, Aníbal, y Sánchez Torres, Yolanda. 2010. Planeación participativa: Teoría y práctica, México, Plaza y Valdés-UAEH.

Terrones Cordero, Aníbal. 2013. Planeación participativa para elaborar un plan de desarrollo municipal: el caso de Acaxochitlán, Hidalgo. In: Economía, Sociedad y Territorio. Vol. 13, Núm. 42, mayo-agosto.
Tillmann, Hermann, y Salas, María. 1994. Nuestro Congreso: Manual de Diagnóstico Rural Participativo, Santiago de Puriscal, PRODAF-GTZ.

Touraine, Alain. 1984. Actores sociales y sistemas políticos en América Latina, Santiago de Chile, PREALC-OIT.

Verdejo, Miguel. 2003. Diagnóstico Rural Participativo. Una guía práctica, Santo Domingo. http://www.entremundos. org/databases/New\%20Training\%20Manuals/expositodiagnostico-rural-participativo.pdf, consultado el 9 de septiembre de 2016.

Vidal, Gregorio. 2012. Actores sociales y gobiernos ante la crisis, México, Editorial Porrúa.

Zamora, Carla. 2011. Crisis rural, cambio climático y pobreza: hacia la búsqueda de alternativas para la definición de políticas públicas en México, México, Oxfam. 